\title{
Change Management Strategies to Implement A Fingerprint Based Attendance System in Information Systems Department Using ADKAR Model
}

\author{
Endang Sulistiyani ${ }^{1^{*}}$, Achmad Holil Noor Ali $^{2}$, dan Hanim Maria Astuti ${ }^{3}$ \\ ${ }^{1}$ Information Systems Department, Universitas Nahdlatul Ulama Surabaya, Surabaya \\ ${ }^{2,3}$ Information System Department, Institut Teknologi Sepuluh Nopember, Surabaya \\ *Corresponding Author \\ E-mail: sulistiyani.endang@unusa.ac.id ${ }^{*}$
}

\begin{abstract}
Information Systems Department has used fingerprints as a student attendance system. But its implementation is briefly, because there are still technical and non-technical problems in the system. Unfortunately, at this time, the fingerprint is only left installed in each classroom and the manual attendance system is reused. It can be seen that the unsuccessful project management is caused by problems in changing from the manual system to the fingerprint system. Based on the ploblems, Information Systems Department of ITS requires change management strategies to implement this system. The planning of change management strategy is initiated by analyzing the gap between the business processes of manual attendance system and of the fingerprint-based attendance system. The goal of this gap analysis is to identify the changes and the impacts which then let to an identification to the solution. The solution will be an input for the development of change management strategy using the perspectives of Awareness, Desire, Knowledge, Ability, Reinforcement (ADKAR) model. The strategy is then mapped according to Prosci's state of change. The result from this research is a change management roadmap of the fingerprint system's implementation. This roadmap contains three states of change, which covering current, transition, and future.
\end{abstract}

Keywords: strategy, change management, fingerprint, $A D K A R$

\section{INTRODUCTION}

Information Systems Department is an organization that has implemented fingerprints as an attendance information system for students. This system is expected to be able to solve problems related to student attendance when a manual attendance system is used. The problem that often occurs is that students often deceive attendance by leaving their signatures to their classmates so that data on manual attendance becomes invalid. Not only that, officers in the academic section also sometimes has difficulties and errors in recording attendance data[1].

Fingerprint-based attendance is an effective method for monitoring student attendance at college. Through this system, students cannot leave attendance with classmates so that cheating can be reduced. The attendance data recapitulation problem is also resolved by having a fingerprint that has been integrated with the attendance information system. The use of paper for attendance forms can also be reduced because the attendance process is carried out directly using the fingerprint installed in each class[1].

Information Systems Department has used fingerprints as a student attendance system. But its implementation is only a few time because there are still technical and non-technical problems in the system [2] . At this time, the fingerprint is only left installed in each classroom and the manual 
attendance system is reused. Meanwhile, according to [2] technically the fingerprint was ready to be used and was integrated with the attendance information system. However, the data is not ready because not all students have registered. The implementation of this system still has many problems on the non-technical side such as the absence of policies, procedures, and problems for students whose fingerprints cannot be read by system.

Based on this phenomenon, it means that there are problems that cause the implementation of fingerprint-based attendance is unsuccessful. Study that conducted by M. Levinson [3] concluded that one of the main causes of failure of a project is the lack of implementation of the change management process, not only in IT but in the organization as a whole. Some examples of project cases that fail due to lack of change management include: (1) a system that is technically and economically feasible but is simply kept quiet and not used, (2) a system developed by the organization's internal team that is also technically and economically feasible but becomes debate in its implementation[4].

Many problems can arise when changes are made, where the most often arises is the rejection of the change itself [5]. Achmad Holil Noor Ali dkk[6] in his research concluded that successful change requires not only effective project management but also good change management. Change management is the application of a structured process and a set of tools to direct people towards changes to achieve the expected outcomes. The purpose of change is to improve the organization by changing how work is done[7]. This was achieved by developing a change management strategy[6]. ADKAR is a change management model that is able to identify why changes are made and helps to determine the steps needed to make a change successful [8]. ADKAR was chosen because it was focused on change at the individual and organizational level. This is different from other change management models which only focus on the organizational level. As stated, the success of change in the organization will be achieved if changes at the individual level are successfully carried out [8].

Based on this problem, Information systems Department requires a structured change management strategy in the implementation of fingerprint-based attendance information systems. Therefore, the main objective of this thesis research is to produce a change management roadmap based on the ADKAR model which is initialized from the analysis of gaps between business processes of current and future attendance activities. This roadmap is expected to help the implementation of fingerprint-based information systems smoothly.

\section{RESEARCH METHODS}

In order to develop a change management strategy, this research was carried out in four main steps. Firstly, exploration of current and future conditions of the absentee business process, second is gap analysis, third is formulation of change management strategies, and the last is validation the strategy. Details of the research methodology are presented in Figure 1.

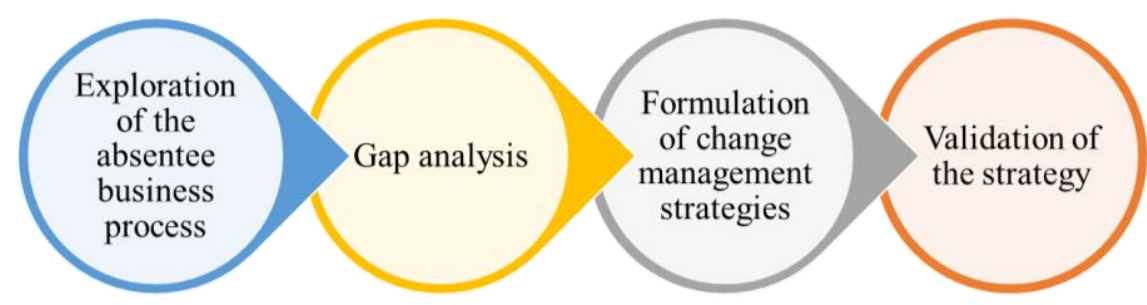

Figure 1. Research Method 
Business process exploration is carried out with three activity, namely: document review, interview, and observation. Documents analyzed are documents related to the development of attendance information systems such as the requirement specification of fingerprint project, policy documents, and fingerprint implementation procedures. While the interviews were conducted directly with management, among them were the IS/IT Coordinator, academic staff, and head of department. This interview was conducted by asking number of questions related to the business process of student attendance activities. Through this method, the current and future conditions of the business attendance system will be obtained. Meanwhile, to find out the current condition of student attendance activities, researchers observe the student attendance process.

The second stage is gap analysis. There are three activities in this stage, namely identification of changes, identifying impacts, and identifying solutions. Changes are identified based on data that has been obtained previously. The results of the gap analysis will show any changes that occur in the components of the business process, both in terms of the process (activities), resources involved, and policy needs, organizational structure, and technology itself. The impact obtained from an IT application is commonly called value. The value is sometimes in the form of benefits that refer to increasing the efficiency of work processes that are applied in the organization and are gray so that it is often referred to as quasi benefits. Quasi benefits are usually analyzed by value linking, value acceleration, value restructuring, and innovation valuation. Furthermore, the solution is initialized to realize the impact that can be obtained from changes that occur using the OCM program, which includes leadership \& sponsorship, governance and compliance, skill and competencies, performance management, organizational design and structure, incentive and rewards, communication, hiring and selection.

Utilizing the results of the gap analysis as well as all data and information obtained from the previous stages, a change management strategy and planning were begun. Change management strategies are prepared using the ADKAR model. Mapping the list of solutions to a list of change management strategies can be helped by mapping the activity or change management tools to the ADKAR element. Next, the list of strategies that have been obtained is then mapped into a state of change from the ADKAR model. This mapping is intended to develop a change management roadmap that accompanies the implementation of a fingerprint-based information system at this department. This change management roadmap will contain a list of strategies from the previous stages which are then organized into a state of change, i.e. current, transition and future for each strategy from each ADKAR element. The regulation of the arrangement is that the current state requires the Awareness and Desire elements of the ADKAR model, the transition state requires the Knowledge and Ability element, while the future state requires the Ability and Reinforcement elements.

The final stage is verification and validation of change management strategies. This process was carried out using interview techniques to conduct discussions with Information System Department management, including the IS/IT Coordinator, academic staff, and head of department to seek approval of the change management roadmap with the ADKAR model that was created.

\section{RESEARCH RESULT AND DISCUSSION}

\subsection{The Current and Future condition of the attendance business process}

The current condition of the attendance business process is the condition of the business process when attendance is done using a manual system. While future conditions refer to attendance business processes using the fingerprint system. The current condition is obtained 
based on the results of interviews with Rio as academic staff and observations. The future conditions were obtained from the results of an interview with Mr. Radityo as IS/IT Coordinator in this department. The both conditions are seen from the 5 focus, namely: process (activity), organizational structure that has a related function, human resources who act as actors, policies, and technology used. The results of exploration of both conditions are presented in Table 1.

Table 1. The Current and Future Condition of Business Process

\begin{tabular}{|c|c|c|}
\hline Focus & Current Condition (as is) & Future Condition (to be) \\
\hline Process & $\begin{array}{ll}\text { 1. } & \text { preparation } \\
\text { 2. } & \text { taking attendance form } \\
\text { 3. } & \text { The attendance } \\
\text { 4. returning attendance form } \\
\text { 5. recapitulation }\end{array}$ & $\begin{array}{ll}\text { 1. } & \text { Fingerprint registration } \\
\text { 2. } & \text { preparation } \\
\text { 3. } & \text { taking attendance form } \\
\text { 4. } & \text { The attendance } \\
\text { 5. } & \text { returning attendance form } \\
\text { 6. } & \text { recapitulation } \\
\end{array}$ \\
\hline $\begin{array}{l}\text { Organizational } \\
\text { structure }\end{array}$ & $\begin{array}{l}\text { Attendance activities is handled by: } \\
\text { Academic unit }\end{array}$ & $\begin{array}{l}\text { Attendance activities are handled by: } \\
\text { 1. Academic unit } \\
\text { 2. IT unit }\end{array}$ \\
\hline $\begin{array}{l}\text { Human } \\
\text { resources }\end{array}$ & $\begin{array}{l}\text { Actors who play a role in } \\
\text { attendance activities are: } \\
\text { 1. Academic staff } \\
\text { 2. Lecturer } \\
\text { 3. Students }\end{array}$ & $\begin{array}{l}\text { Actors who play a role in attendance } \\
\text { activities are: } \\
\text { 1. Academic staff } \\
\text { 2. Lecturer } \\
\text { 3. Students } \\
\text { 4. Fingerprint system }\end{array}$ \\
\hline Policy & $\begin{array}{l}\text { Policy of attendance activities: } \\
\text { 1. Academic regulations for } \\
\text { Chapter IX regarding } \\
\text { academic activities article } 25 \\
\text { paragraph } 4 \\
\text { 2. Policy the way of attendance } \\
\text { process }\end{array}$ & $\begin{array}{l}\text { Policy of attendance activities: } \\
\text { 1. Academic regulations for Chapter IX } \\
\text { regarding academic activities article } 25 \\
\text { paragraph } 4 \\
\text { 2. Policy: rules of limiting time and place } \\
\text { to be considered admissible } \\
\text { 3. Procedures needed for the operation of } \\
\text { a fingerprint-based attendance } \\
\text { information system: } \\
\text { a. Procedure when there is a power } \\
\text { failure } \\
\text { b. Procedure when there is damage to } \\
\text { the tool } \\
\text { c. Procedure when lecturing is not in } \\
\text { class } \\
\text { d. Procedure when the fingerprint is } \\
\text { unreadable }\end{array}$ \\
\hline Technology & $\begin{array}{l}\text { The manual system uses paper as a } \\
\text { medium for attendance }\end{array}$ & $\begin{array}{l}\text { Fingerprint based attendance system, using } \\
\text { fingerprint as a medium for attendance }\end{array}$ \\
\hline Problems & $\begin{array}{l}\text { Some problems with the manual } \\
\text { attendance system: } \\
\text { 1. The system cannot validate } \\
\text { attendance data } \\
\text { 2. The use of paper as a medium } \\
\text { for recording attendance } \\
\text { 3. Recording data is done manually }\end{array}$ & $\begin{array}{l}\text { Some problems with the fingerprint } \\
\text { attendance system: } \\
\text { 1. there are students whose fingerprints } \\
\text { cannot be read } \\
\text { 2. doubts from some students and } \\
\text { lecturers } \\
\text { 4. the time for attendance with a } \\
\text { fingerprint is quite long (about } 15 \\
\text { minutes for one class). } \\
\text { 5. attendance data transparency }\end{array}$ \\
\hline
\end{tabular}




\begin{tabular}{|c|c|c|}
\hline Focus & Current Condition (as is) & Future Condition (to be) \\
\hline & & $\begin{array}{l}\text { 6. procedures for dealing with various } \\
\text { risks besides returning to the manual } \\
\text { system. }\end{array}$ \\
\hline
\end{tabular}

In addition to the explanation regarding the both conditions of the attendance process, this section also shows the problems that exist from each system. Problems with the manual system are the reason for the initiation of the application of the fingerprint system. As for the problems in the fingerprint attendance system will be considered in identifying solutions and change management strategies.

\subsection{Gap Analysis}

Based on the results of the analysis of business process attendance gaps between current conditions (as is) and conditions to come (to be) an example of change is obtained. The list of changes for all aspects is as follows:

a. There is a new sub-process, namely fingerprint registration

b. The attendance form used in class is only the lecturer teaching journal

c. There is one procedure for attendance.

d. The attendance method changed from requiring a signature to fingerprint scanning

e. Data is captured automatically

f. There is the responsibility of the IT department to manage the fingerprint system

The changes identified have several impacts such as the data accuracy, safer attendance data storage, reducing cases of cheating committed by students, there is clarity and uniformity of attendance procedures, and speeding up absenteeism recapitulation. The list of impacts is grouped into value concepts, namely: linking, acceleration, restructuring, and innovation valuation. Value linking is used to evaluate financially the combined impact of the performance improvement function and the permanent results of the separate function. Meanwhile, value acceleration is related to the comparison of acceleration in doing tasks using information technology with the previous one without using information technology. Value Restructuring is the value associated with changes in organizational restructuring related to the impact of information technology. While the value associated with creating new functions in the business domain is commonly called innovation valuation.

Changes and impacts that are identified need solutions to realize them. Solution initialization is carried out using the OCM program, which includes stakeholder analysis, change impact analysis, leadership \& sponsorship, communication programs, key user programs, organizational alignment, work procedure alignment, end user training, and performance support. Some of the solutions identified include: the formulation of new duties and functions for the fingerprint registration guide, providing a fingerprint database storage, the existence of communication media to convey the reasons for change, communicating changes in attendance activities, new policies and procedures, and clarifying the position of IT section in the organizational structure.

\subsection{Change Management Strategies}

A summary of the strategies generated based on mapping the list of solutions to ADKAR elements is presented in Table 2 .

Table 2. List of Change Management Strategies

\begin{tabular}{|l|l|l|}
\hline Number & ADKAR's Element & Strategies \\
\hline 1 & $\begin{array}{l}\text { Awareness of the need for } \\
\text { change }\end{array}$ & $\begin{array}{l}\text { 1. Optimizing the role of superiors } \\
\text { 2. Increased management support }\end{array}$ \\
\hline
\end{tabular}




\begin{tabular}{|c|c|c|}
\hline Number & ADKAR's Element & Strategies \\
\hline & & $\begin{array}{l}\text { 3. Development of effective communication programs to } \\
\text { convey the reasons for change }\end{array}$ \\
\hline 2 & $\begin{array}{l}\text { Desire to support and } \\
\text { participate in the change }\end{array}$ & Development of a conducive environment for change \\
\hline 3 & Knowledge on how to change & Development of education and training programs \\
\hline 4 & $\begin{array}{l}\text { Ability to implement new } \\
\text { skills. }\end{array}$ & $\begin{array}{l}\text { 1. Provide infrastructure needed } \\
\text { 2. Development of a pilot program for implementing the } \\
\text { fingerprint system } \\
\text { 3. Formulation of new job desk } \\
\text { 4. } \text { Making rules and procedures for attendance activities }\end{array}$ \\
\hline 5 & $\begin{array}{l}\text { Reinforcement to sustain the } \\
\text { change. }\end{array}$ & $\begin{array}{l}\text { 1. Optimizing the use of the fingerprint system } \\
\text { 2. }\end{array}$ \\
\hline
\end{tabular}

The strategies that were identified in each element were then arranged into a state of change from Prosci. Solutions on the element of awareness and desire enter the current state, solutions on the knowledge and ability elements enter the transition state, and the future state consists of strategies on the elements of ability and reinforcement. The structuring of the strategy results in a change management roadmap as presented in Figure 2.

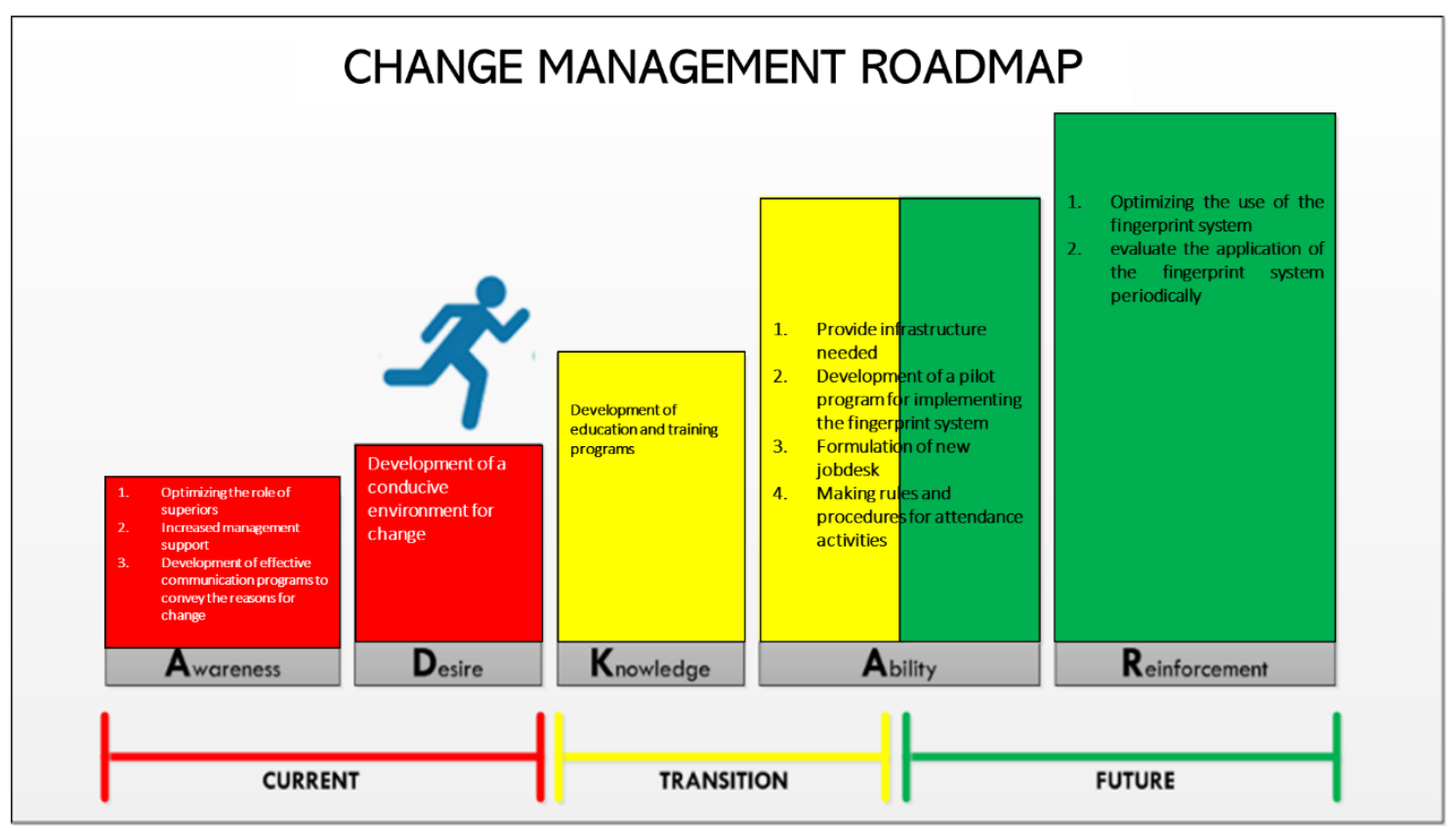

Figure 2. Change Management Roadmap

\subsection{Validation of Change Management Strategies}

The final stage in planning a change management strategy is verification and validation of results. This stage aims to find out whether the strategies proposed by researchers have included the problems and needs that are submitted by the management or not. This verification is carried out by researchers to the management, represented by Mr. Febriliyan Samopa as Head of Information Systems Department.

On this occasion, Mr. Febriliyan Samopa said that there must be alignment of business processes and technology applied to make changes to the attendance system. Other needs that are considered important by the Head department to be prepared for changing the attendance system from manual to fingerprint are as follows: 
1. There are various risks that arise when applying fingerprints as a student attendance system

Head of JSI-ITS stated that "risks such as power failure that might create alternate scenarios outside normal conditions are important. Therefore, the existence of these various risks raises the need to prepare treatment steps so that the attendance process continues".

2. When the system is ready, for fingerprint systems only need a Decree

Head of Department stated that for the determination of the use of the fingerprint system, only need to make a decree. According to this as long as the system is ready, only by making a decree can the change in the use of the attendance system be carried out.

Next is the matching between things needed to change as stated by the Head of department with the change management strategy proposed by the researcher. First, there is a need to prepare steps for handling when alternate scenarios occur so that the attendance process continues. In the change management roadmap proposed by researchers there is one strategy, namely the formulation of rules and procedures for attendance activities. The purpose of this strategy is that in addition to preparing attendance procedures during normal conditions, several procedures in the event of alternate scenarios, which include attendance procedures when the power fails, equipment is broken, fingerprints are not read, and absenteeism in the classroom must be prepared. Not only that, the rules regarding the time provisions for recording absenteeism data and the limitation of time attendance to keep it said are also included in the proposed strategy. Second, a decree is needed for the use of fingerprints as a student attendance system. Although it is not explicitly stated by researchers that a decree is required for fingerprint use, but there is one point of strategy that has the same meaning. Strategies that cover these needs are on the element of awareness, optimizing the role of superiors. This strategy was initiated by the solution to the existence of policy encouragement or rules from the leadership related to the use of the fingerprint system for student attendance systems.

Based on the description above, it is known that the needs needed to change as conveyed by the head of department have been fulfilled in the change management strategy proposed by the researcher. In addition to covering the needs needed to change as conveyed by the Head of department, the strategy proposed by researchers also tries to cover other things needed to make changes. Starting from building awareness to change, creating a desire to participate and support change, to strengthening to safeguard change.

\section{CONCLUSION}

The results showed that the application of the fingerprint system brought changes, which included the addition of new sub processes, namely fingerprint enrollment, changes in attendance procedures, absence of data validation, attendance data recording was done automatically, and the authority of the IT department in managing the fingerprint system as attendance tool. Impacts based on several changes include data accuracy, reducing cases of cheating committed by students, clarity and uniformity in attendance procedures, and accelerating the recapitulation of attendance data. Based on the results of the gap analysis, a change management strategy for implementing a fingerprint system using the ADKAR model is optimizing the role of superiors, increasing management support, and developing effective communication programs to convey the reasons for change, developing a conducive change environment, developing education and training programs for users, providing the infrastructure needed, the development of a pilot program for implementing the fingerprint system, the formulation of new duties and functions, 
and the formulation of rules and procedures for attendance activities, optimizing the use of the fingerprint system, and evaluation of the application of the fingerprint system periodically.

This research is only limited to the preparation of change management strategies with the result is change management roadmap. The preparation of this strategy does not yet include defining KPIs for each proposed strategy. In addition, in the preparation of this strategy, the management of the fingerprint system development project has not been too collaborative in it. Therefore, some further research that can be suggested is adding KPIs as a measure of success for each change management strategy and collaborative project management and change management in strategy development.

\section{DAFTAR PUSTAKA}

[1] N. A. Muhammad, F. Samopa, and R. P. Wibowo, "Pembuatan Aplikasi Presensi Perkuliahan Berbasis Fingerprint (Studi Kasus: Jurusan Sistem Informasi Institut Teknologi Sepuluh Nopember Surabaya)," J. Tek. ITS, vol. 2, no. 3, pp. A465--A469, 2013.

[2] Wibowo, R. P. (2014, December 5). Kesiapan Penerapan Absensi berbasis Fingerprint Mahasiswa JSI-ITS. (E. Sulistiyani, Interviewer)

[3] M. Levinson. ((2006)). When Failure is Not Option. Framingham.

[4] A. Subiyakto, "Manajemen Perubahan Dalam Pengembangan Sistem Informasi Perguruan Tinggi," in Seminar Nasional Riset Teknologi Informasi (SRITI). Agustus, 2008.

[5] R. D. Gunawan, R. R. Suryono, and I. Purwanto, "Analisa Perubahan Manajemen Dalam Implementasi Si/ti Pada Perguruan Tinggi ABC," in Seminar Nasional Aplikasi Teknologi Informasi (SNATI), 2010.

[6] A. H. N. Ali, E. W. T. Darmaningrat, and D. D. Winardi, "Change Management Strategies of E-Learning Adoption In Secondary Schools: A Case Study of Public Junior High Schools in Surabaya," in Proceedings of the 2018 2nd International Conference on Education and E-Learning, 2018, pp. 140-145.

[7] G. Xiong, A. Zhao, T. R. Nyberg, and G. Xiong, "Change management on improvement project for success," in 2016 IEEE International Conference on Service Operations and Logistics, and Informatics (SOLI), 2016, pp. 53-59.

[8] Overview:ADKAR. (2014). Retrieved December 1, 2014, from Change Management Tutorial Series: http://www.change-management.com/tutorial-adkar-overview-mod2.htm

[9] D. Anderson, \& L.A. Anderson. (2001). Beyond Change Management: Advanced Strategies for Todays transformational Leaders. USA: Jossey-Bass.

[10] Gunawan, R. D., Suryono, R. R., \& Purwanto, I. (2010). Analisa Perubahan Manajemen dalam implementasi SI/TI pada Perguruan Tinggi ABC. Seminar Nasional Aplikasi Teknologi Informasi 2010 (SNATI 2010), STMIK Teknokrat, Lampung 